\title{
The effect of sieve mesh size on the description of macroinvertebrate communities
}

\author{
Beatriz Barba, Aitor Larrañaga*, Ainhoa Otermin, Ana Basaguren and Jesús Pozo
}

Lab. Ecología de ríos, Dpto. Biología Vegetal y Ecología, Fac. Ciencia y Tecnología, Universidad del País Vasco/E. H. U., Apdo. 644. 48080 Bilbao.

* Corresponding author: aitor.larranagaa@ehu.es

Received: 23/9/09 Accepted: 6/2/10

\begin{abstract}
The effect of sieve mesh size on the description of macroinvertebrate communities

Considerable time and effort is required to estimate the abundance and biomass of benthic macroinvertebrates, and often variable mesh size sieves are used to clean collected samples. We test whether the use of a mesh with a $1 \mathrm{~mm}$ pore size is adequate to obtain a valid description of a benthic macroinvertebrate community. Stream benthic surber samples were collected from 24 headwater streams. The densities, biotic indices and biological traits of macroinvertebrates retained in a $1 \mathrm{~mm}$ mesh ('>1 mm' fraction) were compared to the same descriptors for the of macroinvertebrates retained in a $0.5 \mathrm{~mm}$ mesh sieve ('total'). We found that, if only the large fraction $(>1 \mathrm{~mm})$ is examined, the community descriptors are affected. Nevertheless, the observed changes were proportional and predictable for all of the variables describing invertebrate communities. Statistical differentiation of the tested metrics between sites was similar for both mesh sizes. Depending on the aim of the study (e.g., environmental impact assessments), the use of a $1 \mathrm{~mm}$ mesh sieve would be sufficient in describing macroinvertebrate communities.
\end{abstract}

Key words: Benthos, macroinvertebrates, processing, effort, mesh size.

\section{RESUMEN}

\section{Efecto del tamaño de poro del tamiz en la descripción de las comunidades de macroinvertebrados}

Para las estimas de abundancia y biomasa, el procesado de las muestras en laboratorio de invertebrados bentónicos requiere un tiempo y esfuerzo considerable y generalmente implica el uso de tamices de diferente luz de malla para lavar la muestra. Nuestro trabajo trata de comprobar si es suficiente para una descripción válida de la comunidad el uso de un tamiz de malla de $1 \mathrm{~mm}$ de poro en el procesado de muestras. Con tal propósito se recogieron muestras bentónicas de río en 24 tramos de cabecera y se compararon densidades, índices bióticos y rasgos biológicos de los invertebrados que eran retenidos en un tamiz. de luz de malla de $1 \mathrm{~mm}$ (fracción '>1 mm') con los obtenidos usando una de $0.5 \mathrm{~mm}$ ('total'). Nuestro estudio revela que el análisis exclusivo de la malla gruesa afecta a los descriptores de la comunidad. Sin embargo, los cambios observados son proporcionales para todas las variables y se pueden predecir bien con ecuaciones lineales. Por otro lado, la diferenciación estadística entre estaciones es similar usando ambos tipos de malla, lo que en definitiva sugiere que, dependiendo del objetivo del estudio (por ejemplo, evaluación de impacto ambiental), el examen de la fauna retenida en un tamiz de $1 \mathrm{~mm}$ de poro puede ser suficiente para la descripción de las comunidades de macroinvertebrados.

Palabras clave: Bentos, macroinvertebrados, procesado, esfuerzo, tamaño del poro de malla.

\section{INTRODUCTION}

Benthic macroinvertebrates are the primary group of organisms used in stream water quality moni- toring programs (Metcalfe-Smith, 1996; Bonada et al., 2006). Sorting benthic macroinvertebrates from sediments and organic matter, as well as counting and identifying them, takes consi- 
derable time and effort (Ciborowski, 1991; Vlek et al., 2006). While an exhaustive sorting of samples is the only way to assure a thorough description of the structure and composition of a macroinvertebrate community (Courtemanch, 1996; Cao et al., 1998), techniques that optimize the cost-benefit for processing the samples have been developed (e.g. Barbour \& Gerritsen, 1996; Vinson \& Hawkins, 1996; Walsh, 1997; Metzeling \& Miller, 2001; Vlek et al., 2006).

The manner in which samples are collected and processed influences the description of the macroinvertebrate community being examined (Tanaka \& Leite, 1998; Morin et al., 2004; Boonsoong et al., 2009); mesh size is a primary influencing factor (Battle et al., 2007; Buss \& Borges, 2008). A fine mesh gives a more precise estimate of the community but increases the effort needed for processing (Bartsch et al., 1998). Thus a compromise between precision and effort must be made and can be achieved by using a larger mesh size.

Concerns about the imprecision of the estimates obtained using different mesh sizes would be negligible if the variation of the community parameters was kept to a minimum, if the changes of these values were predictable or if statistical discrimination between sites was similar. Our objectives were to test the following questions: 1$)$ whether mesh size ( $1 \mathrm{~mm}$ or $0.5 \mathrm{~mm}$ ) affected macroinvertebrate community descriptors, such as density, taxonomic richness, biotic indices or other metrics based on biological traits; 2) whether there was a relationship between the metrics obtained by both meshes and 3 ) whether significant differences between sites remained consistent independent of the mesh size used.

\section{METHODS}

\section{Study sites}

Our study was conducted in 24 streams that drain over siliceous materials in tributaries of rivers in the Northern Iberian Peninsula (15 sites were in Agüera, 4 sites were in Barbadún, 3 sites we-

Table 1. Main characteristics of the study sites (mean $\pm \mathrm{SE}$ ) during the three months before sampling $(N=8 ; \mathrm{DIN}=$ dissolved inorganic nitrogen, SRP = soluble reactive phosphorus). Características principales de las estaciones estudiadas (promedio \pm EE) en los tres meses previos a los muestreos $(\mathrm{n}=8)$. DIN = nitrógeno inorgánico disuelto, SRP = fósforo reactivo soluble.

\begin{tabular}{|c|c|c|c|c|c|c|c|c|}
\hline Site & Stream order & $\begin{array}{c}\text { Temp } \\
\left({ }^{\circ} \mathbf{C}\right)\end{array}$ & $\mathbf{p H}$ & $\begin{array}{c}\text { Alkalinity } \\
\text { (meq/l) }\end{array}$ & $\begin{array}{c}\text { Conductivity } \\
(\mu \mathrm{S} / \mathrm{cm})\end{array}$ & $\begin{array}{c}\text { Oxygen sat. } \\
(\%)\end{array}$ & $\begin{array}{c}\text { DIN } \\
(\mu \mathrm{g} \mathrm{N} / \mathrm{l})\end{array}$ & $\begin{array}{c}\text { SRP } \\
(\mu \mathrm{g} \mathrm{P} / \mathrm{l})\end{array}$ \\
\hline 1 & 2 & $9.7 \pm 0.6$ & $7.1 \pm 0.1$ & $0.48 \pm 0.04$ & $106.0 \pm 4.6$ & $96.8 \pm 0.6$ & $804 \pm 58.1$ & $13.2 \pm 3.7$ \\
\hline 2 & 1 & $10.1 \pm 0.6$ & $7.3 \pm 0.1$ & $0.80 \pm 0.09$ & $140.7 \pm 8.5$ & $97.7 \pm 1.8$ & $1130 \pm 129.7$ & $301.2 \pm 68.7$ \\
\hline 3 & 1 & $9.5 \pm 0.5$ & $7.2 \pm 0.1$ & $0.63 \pm 0.05$ & $135.5 \pm 4.2$ & $100.3 \pm 2.3$ & $774 \pm 80.6$ & $17.0 \pm 7.1$ \\
\hline 4 & 3 & $10.8 \pm 0.5$ & $7.8 \pm 0.1$ & $2.30 \pm 0.08$ & $281.9 \pm 8.3$ & $95.3 \pm 1.4$ & $1217 \pm 46.4$ & $37.2 \pm 8.8$ \\
\hline 5 & 1 & $10.4 \pm 0.3$ & $7.4 \pm 0.1$ & $1.18 \pm 0.07$ & $183.0 \pm 6.0$ & $95.4 \pm 0.4$ & $262 \pm 61.8$ & $14.5 \pm 7.9$ \\
\hline 6 & 1 & $10.8 \pm 0.4$ & $7.3 \pm 0.1$ & $1.15 \pm 0.05$ & $191.3 \pm 4.9$ & $95.8 \pm 1.6$ & $515 \pm 42.8$ & $15.7 \pm 2.6$ \\
\hline 7 & 1 & $10.9 \pm 0.5$ & $7.3 \pm 0.1$ & $0.91 \pm 0.03$ & $133.55 \pm 7.9$ & $97.6 \pm 0.5$ & $538 \pm 48.3$ & $5.0 \pm 2.1$ \\
\hline 8 & 1 & $11.4 \pm 0.5$ & $7.2 \pm 0.1$ & $0.97 \pm 0.04$ & $143.4 \pm 5.82$ & $80.8 \pm 0.9$ & $818 \pm 61.8$ & $13.7 \pm 3.2$ \\
\hline 9 & 2 & $9.9 \pm 0.4$ & $7.1 \pm 0.1$ & $0.41 \pm 0.02$ & $101.4 \pm 3.1$ & $100.2 \pm 1.9$ & $558 \pm 48.4$ & $3.7 \pm 1.6$ \\
\hline 10 & 3 & $10.7 \pm 0.3$ & $7.4 \pm 0.1$ & $0.72 \pm 0.04$ & $134.7 \pm 5.8$ & $98.6 \pm 0.7$ & $894 \pm 58.2$ & $19.7 \pm 6.5$ \\
\hline 11 & 2 & $9.8 \pm 0.6$ & $7.2 \pm 0.1$ & $0.50 \pm 0.04$ & $84.5 \pm 7.6$ & $105.4 \pm 4.7$ & $505 \pm 51.4$ & $9.4 \pm 2.4$ \\
\hline 12 & 2 & $10.0 \pm 0.6$ & $7.2 \pm 0.1$ & $0.46 \pm 0.04$ & $82.8 \pm 6.9$ & $105.3 \pm 3.4$ & $480 \pm 40.7$ & $8.6 \pm 5.6$ \\
\hline 13 & 1 & $10.9 \pm 0.6$ & $6.4 \pm 0.2$ & $0.16 \pm 0.02$ & $67.6 \pm 3.4$ & $100.0 \pm 1.5$ & $1609 \pm 108.1$ & $6.2 \pm 3.2$ \\
\hline 14 & 1 & $11.2 \pm 0.8$ & $6.1 \pm 0.1$ & $0.12 \pm 0.01$ & $67.0 \pm 3.3$ & $98.7 \pm 1.3$ & $509 \pm 48.8$ & $9.7 \pm 5.1$ \\
\hline 15 & 1 & $9.4 \pm 0.7$ & $7.5 \pm 0.2$ & $0.95 \pm 0.09$ & $141.1 \pm 13.2$ & $99.0 \pm 1.5$ & $1169 \pm 48.6$ & $3.4 \pm 2.1$ \\
\hline 16 & 1 & $11.4 \pm 1.2$ & $6.6 \pm 0.1$ & $0.44 \pm 0.18$ & $96.2 \pm 19.2$ & $98.5 \pm 1.7$ & $609 \pm 71.6$ & $8.5 \pm 4.8$ \\
\hline 17 & 1 & $9.2 \pm 0.7$ & $7.0 \pm 0.1$ & $0.27 \pm 0.02$ & $93.3 \pm 4.4$ & $98.1 \pm 1.3$ & $962 \pm 53.9$ & $6.6 \pm 2.3$ \\
\hline 18 & 1 & $10.3 \pm 0.7$ & $7.1 \pm 0.1$ & $0.75 \pm 0.08$ & $214.2 \pm 17.9$ & $99.8 \pm 1.7$ & $828 \pm 123.7$ & $7.53 \pm 3.5$ \\
\hline 19 & 1 & $10.6 \pm 0.8$ & $6.8 \pm 0.1$ & $0.23 \pm 0.02$ & $64.8 \pm 4.8$ & $100.0 \pm 1.6$ & $317 \pm 33.8$ & $4.4 \pm 1.89$ \\
\hline 20 & 1 & $10.7 \pm 0.9$ & $7.1 \pm 0.1$ & $0.43 \pm 0.04$ & $119.8 \pm 14.8$ & $101.2 \pm 1.2$ & $753 \pm 94.5$ & $8.1 \pm 2.4$ \\
\hline 21 & 2 & $11.8 \pm 0.4$ & $6.5 \pm 0.1$ & $1.88 \pm 0.12$ & $82.8 \pm 2.6$ & $99.1 \pm 0.6$ & $1438 \pm 202.6$ & $6.0 \pm 3.2$ \\
\hline 22 & 2 & $10.6 \pm 0.4$ & $7.2 \pm 0.1$ & $3.86 \pm 0.07$ & $154.6 \pm 9.6$ & $98.7 \pm 0.9$ & $1591 \pm 121.6$ & $102.1 \pm 14.9$ \\
\hline 23 & 1 & $12.6 \pm 0.4$ & $7.8 \pm 0.1$ & $1.84 \pm 0.25$ & $491.9 \pm 7.2$ & $96.3 \pm 0.9$ & $1728 \pm 327.7$ & $80.2 \pm 8.3$ \\
\hline 24 & 2 & $12.0 \pm 0.4$ & $7.4 \pm 0.1$ & $1.79 \pm 0.12$ & $363.6 \pm 27.6$ & $94.5 \pm 2.6$ & $1751 \pm 197.2$ & $53.7 \pm 11.4$ \\
\hline
\end{tabular}


re in Sámano, and 2 sites were in Asón; see Table 1 for water physical-chemical characteristics). The climate is temperate, the annual precipitation rate is around $1600 \mathrm{~mm}$, and the mean annual temperature is $14.3{ }^{\circ} \mathrm{C}$. The primary land uses in this area are forestry, agriculture and stock breeding (Elosegi et al., 2002).

\section{Collecting and processing of benthic macroinvertebrate samples}

In February and March 2003 (hereafter referred to as 'sampling 1') benthic samples were collected (Surber, $900 \mathrm{~cm}^{2}$ area using a mesh with a $0.5 \mathrm{~mm}$ pore size) from sites 1 to 20 (five samples from randomly selected riffles) and were preserved in $70 \%$ alcohol. Samples were sieved through a $1 \mathrm{~mm}$ mesh, which created two fractions: one captured in the $1 \mathrm{~mm}$ mesh sieve (referred to as the ' $>1 \mathrm{~mm}$ ' fraction) and one filtered through it. We refer to the sum of these two fractions as the 'total sample'. Specimens were identified to genus (Plecoptera, Ephemeroptera and Crustacea), family, or class (Oligochaeta) following Tachet et al. (2002). In December 2003 , a second benthic sample was taken (hereafter referred to as 'sampling 2') in sites 21 to 24 and samples were processed following the same methods outlined for 'sampling 1'.

\section{Data analysis}

\section{Indices}

For 'sampling 1', we calculated eight indices for each data set ('>1 mm fraction' and 'total sample') and each site (one value per site was obtained from the lumped abundances of the five replica): taxonomic richness; Shannon diversity index (H) (Begon et al., 1997); IBMWP (Iberian Biological Monitoring Working Party) (AlbaTercedor \& Pujante, 2000); IASPT (Iberian Average Score Per Taxon; calculated by dividing the IBMWP score by the number of families in each sample); EPT (Ephemeroptera, Plecoptera and Trichoptera) richness; percentage of shredders; percentage of other primary consumers and percentage of secondary consumers. While the me- thodology for the IBMWP proposes the use of a kick net of $0.3 \mathrm{~mm}$ for sampling, we argue that a Surber net of $0.5 \mathrm{~mm}$ was sufficient in enabling us to calculate the IBMWP values; Torralba Burriel \& Ocharan, (2007) found high similarities in their results obtained with the two types of nets, and we aim only to achieve internal comparability.

\section{Biological and ecological traits}

The analysis of biological and ecological traits focussed on shredder assemblages, a functional feeding group that reacts more clearly than others to environmental stressors in these highly organic matter dependant streams (Larrañaga, 2008; Larrañaga et al., 2009). We analysed the following: maximum body size, life cycle length, number of reproduction cycles per year, dispersal rates, food, $\mathrm{pH}$ preference and trophic status preference. We ranked details about the traits as theoretical affinity scores for each modality within each trait at the genus level (Tachet et al., 2002). Scores for each genus were multiplied by their density, and the resultant values for each modality for all genera were summed. Finally, relative scores for each modality were calculated for the shredder assemblage by dividing the total score in the modality by the total score for the corresponding trait.

\section{Statistical analyses}

We used three statistical approaches for our analysis. First, values of the indices obtained in the '>1 mm fraction' were contrasted with those obtained in the 'total sample', using $t$-tests for paired data $(N=20)$. Second, regression analyses between the values calculated from the '>1 mm fraction' and from the 'total sample' were performed for densities $\left(\mathrm{n}^{\circ} \mathrm{m}^{-2}\right)$ of total invertebrates, feeding guilds and the most abundant taxa (mean relative density $>5 \%$ ), as well as for the relative scores of the trait modalities of shredders (untransformed data; $N=99$; independent variable: '>1 mm fraction'). Third, we tested whether the between sites multiple comparisons remained unchanged with the '>1 mm fraction' or the 'total sample' (hereafter referred to as interpretation analysis; data were log-transformed 
Table 2. Comparison and regression analyses of the descriptors between the ' $>1 \mathrm{~mm}$ fraction' and 'total sample' $(N=20 ; p<0.001$ in all regressions). Comparación y análisis de regresión de los descriptores entre ' $>1$ mm' y 'total' ( $\mathrm{n}=20$; $\mathrm{p}<0$,001 en todas las regresiones).

\begin{tabular}{lrrrrrrrr}
\hline \multirow{2}{*}{ Index } & \multicolumn{4}{c}{ Comparison } & \multicolumn{3}{c}{ Regression 'total' vs '> 1 mm' } \\
\cline { 2 - 8 } & '> $\mathbf{1}$ mm' & 'total' & \multicolumn{1}{c}{$\boldsymbol{t}$} & $\boldsymbol{p}$ & $\boldsymbol{b}$ & \multicolumn{1}{c}{ Cte } & $\boldsymbol{R}^{2}$ & $\boldsymbol{F}$ \\
\hline Taxonomic richness & 27.2 & 32.4 & 10.46 & $<0.001$ & 0.860 & 9.047 & 0.72 \\
Shannon diversity & 2.4 & 2.3 & 1.48 & $\mathrm{~ns}$ & 0.951 & 0.082 & 0.92 & 215.9 \\
IBMWP & 172.6 & 201.1 & 11.55 & $<0.001$ & 0.978 & 32.327 & 0.88 & 126.0 \\
IASPT & 6.3 & 6.2 & 3.25 & 0.004 & 0.665 & 1.964 & 0.65 & 33.3 \\
EPT richness & 16.5 & 19.1 & 1.97 & $\mathrm{~ns}$ & 0.874 & 4.622 & 0.82 & 81.5 \\
Shredder \% & 18.6 & 20.7 & 2.30 & 0.033 & 1.099 & 0.305 & 0.89 & 155.0 \\
Other primary consumer \% & 75.5 & 74.4 & 1.03 & $\mathrm{~ns}$ & 1.045 & -4.437 & 0.88 & 135.8 \\
Secondary consumer \% & 5.9 & 4.9 & 3.38 & 0.003 & 0.736 & 0.482 & 0.83 & 88.0 \\
\hline
\end{tabular}

to approximate normality following Zar, 1999). We performed Tukey tests among the 20 sites (190 comparisons) for the '>1 mm fraction' and for the 'total sample' for the density and the trait related variables. We counted the number of pairwise comparisons for each variable that led to the same conclusion with both data sets (both sites being either statistically equal or statistically different); we considered these cases as 'equal' results. Alternatively, the number of comparisons that had significant differences between sites of the '>1 mm fraction' but not between sites of the 'total sample' were considered type I errors. Finally, we computed the number of comparisons between sites that were not significantly different considering the ' $>1 \mathrm{~mm}$ fraction' but different when considering the 'total sample' (type II errors).

'Sampling 2' was used to validate the relationships observed between the ' $>1 \mathrm{~mm}$ fraction' and the 'total sample' obtained in 'Sampling 1'. Predictions of density in the 'total sample' for 'Sampling 2' were determined using regression equations constructed with the 'sampling 1' data set. The predicted values were thereafter compared with the 'total sample' observed values of 'sampling 2' by $t$-tests for paired data $(N=20)$. All statistical analyses were performed with SPSS 14.0 for Windows.

\section{RESULTS}

We found 67 taxa in the 'total sample', 61 of which also appeared in the ' $>1 \mathrm{~mm}$ fraction'. The only taxa that appeared exclusively in the 'total sample' (albeit in low densities) were Tabanidae ( $0.039 \%$ of total abundance), Asellus $(0.022 \%)$, Molannidae $(0.017 \%)$, Psychomyi-

Table 3. Mean densities in the 'total sample' and the percentage of individuals lost when examining only the ' $>1 \mathrm{~mm}$ fraction'. The regression and interpretation analyses (see Methods) for the total invertebrates, the feeding guilds and the abundant taxa are included $(N=99 ; p<0.001$ in all regressions). Densidades medias en el 'total' y porcentaje de individuos perdidos al estudiar sólo '>1 mm' junto con el análisis de regresión e interpretación (ver Methods) de la densidad total de invertebrados, de los grupos de alimentación $y$ de los taxones abundantes $(\mathrm{n}=99 ; \mathrm{p}<0,001$ en todas las regresiones).

\begin{tabular}{|c|c|c|c|c|c|c|c|c|c|}
\hline \multirow{2}{*}{ Variable } & \multirow{2}{*}{$\frac{\text { Mean density }}{\left(\mathbf{n}^{0} \mathbf{m}^{-2}\right)}$} & \multirow{2}{*}{$\begin{array}{l}\% \text { lost in } \\
\text { '>1 mm' }\end{array}$} & \multicolumn{4}{|c|}{ Regression } & \multicolumn{3}{|c|}{ Interpretation } \\
\hline & & & $b$ & cte & $R^{2}$ & $F$ & Equal & Error I & Error II \\
\hline Total invertebrates & 4028.4 & 50.4 & 1.852 & 329.8 & 0.87 & 638.5 & 188 & 2 & 0 \\
\hline Shredders & 731.9 & 56.7 & 1.894 & 131.9 & 0.78 & 354.1 & 182 & 8 & 0 \\
\hline Echinogammarus & 411.1 & 55.8 & 1.748 & 90.8 & 0.78 & 346.7 & 174 & 8 & 8 \\
\hline Other primary consumers & 3140.9 & 49.5 & 1.892 & 139.9 & 0.88 & 693.5 & 178 & 9 & 3 \\
\hline Baetis & 678.9 & 55.1 & 1.727 & 146.5 & 0.87 & 648.8 & 186 & 4 & 0 \\
\hline Elmidae & 254.6 & 59.2 & 2.078 & 36.6 & 0.91 & 1022.3 & 179 & 2 & 9 \\
\hline Oligochaeta & 324.3 & 44.0 & 1.459 & 47.3 & 0.83 & 219.9 & 178 & 1 & 11 \\
\hline Simuliidae & 354.9 & 35.2 & 1.258 & 62.9 & 0.95 & 1694.0 & 181 & 5 & 4 \\
\hline Chironomidae & 1000.3 & 55.4 & 1.696 & 202.4 & 0.85 & 559.1 & 174 & 4 & 12 \\
\hline Secondary consumers & 155.5 & 39.5 & 1.276 & 35.5 & 0.64 & 172.0 & 180 & 0 & 10 \\
\hline
\end{tabular}


Table 4. Regression and interpretation analysis (see Methods) of the different modalities of the biological and ecological traits for the shredder assemblages $(N=99 ; p<0.001$ in all analyses). Análisis de regresión e interpretación (ver Methods) de las diferentes modalidades de los rasgos biológicos y ecologicos del grupo de los fragmentadores ( $\mathrm{n}=99 ; \mathrm{p}<0,001$ en todos los casos).

\begin{tabular}{|c|c|c|c|c|c|c|c|c|}
\hline \multirow{2}{*}{ Trait } & \multirow{2}{*}{ Modality } & \multicolumn{4}{|c|}{ Regression } & \multicolumn{3}{|c|}{ Interpretation } \\
\hline & & $b$ & Cte & $R^{2}$ & $\boldsymbol{F}$ & Equal & Error I & Error II \\
\hline \multirow{5}{*}{ Maximum body size } & $<2.5 \mathrm{~mm}$ & 0.930 & 1.48 & 0.50 & 96.8 & 168 & 15 & 7 \\
\hline & $2.5-5 \mathrm{~mm}$ & 0.881 & 3.89 & 0.53 & 111.4 & 164 & 18 & 8 \\
\hline & $5-10 \mathrm{~mm}$ & 0.875 & 3.69 & 0.91 & 934.2 & 168 & 9 & 13 \\
\hline & $10-20 \mathrm{~mm}$ & 0.760 & 1.79 & 0.85 & 563.3 & 168 & 3 & 19 \\
\hline & $20-40 \mathrm{~mm}$ & 0.883 & 2.91 & 0.93 & 1253.3 & 165 & 8 & 17 \\
\hline \multirow{2}{*}{ Life cycle length } & $\leq$ year & 0.818 & 5.60 & 0.90 & 843.1 & 166 & 6 & 18 \\
\hline & $>1$ year & 0.818 & 12.63 & 0.90 & 843.1 & 169 & 5 & 16 \\
\hline \multirow{3}{*}{ Reproduction cycles per year } & $<1$ & 0.854 & 1.47 & 0.79 & 375.6 & 171 & 0 & 19 \\
\hline & 1 & 0.862 & 7.88 & 0.91 & 1006.5 & 168 & 4 & 18 \\
\hline & $>1$ & 0.892 & 3.26 & 0.93 & 1324.1 & 176 & 2 & 12 \\
\hline \multirow{4}{*}{ Dispersion } & Aquatic passive & 0.887 & 4.73 & 0.91 & 951.5 & 172 & 12 & 6 \\
\hline & Aquatic active & 0.821 & 4.88 & 0.84 & 500.2 & 168 & 13 & 9 \\
\hline & Aerial passive & 0.521 & 0.03 & 0.81 & 406.1 & 186 & 3 & 1 \\
\hline & Aerial active & 0.913 & 3.66 & 0.78 & 340.3 & 171 & 9 & 10 \\
\hline \multirow{8}{*}{ Food } & Fine sedim. + microorg. & 0.709 & 0.00 & 0.76 & 309.3 & 190 & 0 & 0 \\
\hline & FPOM & 0.819 & 2.43 & 0.83 & 476.3 & 167 & 3 & 20 \\
\hline & CPOM & 0.502 & 15.17 & 0.32 & 44.8 & 169 & 3 & 18 \\
\hline & Microphytes & 0.963 & 2.20 & 0.70 & 227.9 & 169 & 3 & 18 \\
\hline & Macrophytes & 0.698 & 2.95 & 0.62 & 155.0 & 154 & 2 & 34 \\
\hline & Dead animals $>1 \mathrm{~mm}$ & 0.736 & 2.99 & 0.77 & 332.3 & 175 & 5 & 10 \\
\hline & Microinvertebrates & 0.910 & 0.67 & 0.91 & 931.1 & 166 & 10 & 14 \\
\hline & Macroinvertebrates & 0.885 & 0.36 & 0.87 & 652.4 & 156 & 9 & 25 \\
\hline \multirow{6}{*}{$\mathrm{pH}$ preference } & $<4$ & 0.841 & 1.26 & 0.84 & 513.8 & 181 & 1 & 8 \\
\hline & $4-4.5$ & 0.850 & 1.40 & 0.88 & 728.6 & 177 & 6 & 7 \\
\hline & $4.5-5$ & 0.587 & 7.16 & 0.51 & 99.8 & 178 & 7 & 5 \\
\hline & $5-5.5$ & 0.819 & 3.66 & 0.87 & 652.3 & 171 & 4 & 15 \\
\hline & $5.5-6$ & 0.871 & 2.60 & 0.88 & 724.3 & 173 & 10 & 7 \\
\hline & $>6$ & 0.865 & 2.99 & 0.90 & 884.5 & 173 & 2 & 15 \\
\hline \multirow{3}{*}{ Trophic status preference } & Oligotrophic & 0.630 & 19.7 & 0.60 & 147.4 & 165 & 15 & 10 \\
\hline & Mesotrophic & 0.680 & 14.7 & 0.67 & 200.5 & 152 & 18 & 20 \\
\hline & Eutrophic & 0.767 & 0.69 & 0.55 & 120.2 & 172 & 18 & 0 \\
\hline
\end{tabular}

dae $(0.017 \%)$, Psephenidae $(0.005 \%)$ and Valvatidae $(0.005 \%)$. Mesh size did not significantly affect the values obtained for the Shannon diversity index or for the EPT richness index. Taxa richness and the IBMWP index, however, were significantly higher and the IASPT was significantly lower for the 'total sample' than for the '> $1 \mathrm{~mm}$ fraction' (Table 2). Considering IBMWP quality classes, 5 of the 20 sites (sites 4, 8, 9, 13 and 14) changed quality classes with mesh size.; they were classified as 'non-contaminated' or 'non-significantly altered' (IBMWP: 100-150) with values from the ' $>1 \mathrm{~mm}$ fraction' and they were changed to the clean wa- ters category (IBMWP > 150) when the 'total sample' was examined. Relative contribution of shredders was significantly lower in the ' $>1 \mathrm{~mm}$ fraction' than in the 'total sample'; for secondary consumers relative contribution was higher in the '>1 mm fraction' and other primary consumers did not differ between fractions (Table 2). Regression analyses between the ' $>1 \mathrm{~mm}$ fraction' and the 'total sample' were significant for all the indices analysed (Table 2).

When only the '>1 mm fraction' was processed, $50.4 \%$ of the 35893 individuals collected in 'sampling 1' were lost (Table 3). Among the most abundant taxa, Elmidae suf- 
Table 5. Comparison of the observed and estimated densities (mean \pm SE) for the total invertebrates, the feeding guilds and the abundant taxa for the 'sampling 2' sites $(N=20)$. Comparación de las densidades observadas y esperadas del total de invertebrados, de los grupos de alimentación y de los taxones abundantes para las estaciones del segundo muestreo ('sampling 2') (n = 20).

\begin{tabular}{|c|c|c|c|c|}
\hline \multirow{2}{*}{ Variable } & \multicolumn{2}{|c|}{ Average density $\left(\mathbf{n}^{\mathbf{0}} \mathbf{m}^{-2} \pm \mathrm{SE}\right)$} & \multicolumn{2}{|c|}{ Comparison } \\
\hline & Observed & Estimated & $t$ & $p$ \\
\hline Total invertebrates & $6792.6 \pm 1428.8$ & $6685.4 \pm 1523.7$ & 0.77 & ns \\
\hline Shredders & $632.6 \pm 151.9$ & $636.6 \pm 151.6$ & 1.82 & ns \\
\hline Echinogammarus & $100.7 \pm 32.5$ & $57.5 \pm 27.7$ & 1.32 & ns \\
\hline Other primary consumers & $5957.8 \pm 1419.0$ & $5921.0 \pm 1456.6$ & 1.29 & ns \\
\hline Baetis & $211.1 \pm 36.9$ & $116.0 \pm 18.0$ & 2.29 & 0.03 \\
\hline Elmidae & $278.5 \pm 52.5$ & $325.0 \pm 71.3$ & 1.51 & ns \\
\hline Oligochaeta & $507.4 \pm 85.8$ & $734.0 \pm 115.8$ & 2.79 & 0.01 \\
\hline Simuliidae & $75.5 \pm 12.6$ & $74.6 \pm 11.2$ & 0.12 & ns \\
\hline Chironomidae & $950.4 \pm 117.2$ & $882.7 \pm 115.0$ & 0.89 & ns \\
\hline Secondary consumers & $202.2 \pm 28.1$ & $127.8 \pm 20.6$ & 4.22 & $<0.001$ \\
\hline
\end{tabular}

fered the highest losses $(59.2 \%)$ and Simuliidae suffered the fewest losses $(35.2 \%)$ when examining just the ' $>1 \mathrm{~mm}$ fraction' (Table 3 ). Regression analyses between the abundance of the feeding groups and the most abundant taxa in the ' $>1 \mathrm{~mm}$ fraction' and the 'total sample' were significant $(p<0.001$, Table 3$)$. Abundance of Simuliidae, Elmidae and 'other primary consumers' had the best fit to the data, whereas 'secondary consumers' abundance had the worst fit (Table 3). Among the 190 possible comparisons (of abundances) between the 20 sites, the 'equal' cases (those that reach the same statistical conclusion studying both fractions) ranged from 174 (Echinogammarus) to 188, depending on the taxon or group analysed (average $=180$; $94.7 \%$ of the possible pairwise comparisons; Table 3). Type I errors (differences in the ' $>1 \mathrm{~mm}$ fraction' and not in the 'total sample') ranged from 0 to 9 cases, whereas type II errors ranged from 0 to 12 cases (Table 3 ).

All linear regressions for the relative affinity scores of biological traits between the ' $>1 \mathrm{~mm}$ fraction' and the 'total sample' were significant ( $p<0.001 ; R^{2}$ range: $0.32-0.91$; Table 4 ). Of the 190 Tukey tests performed, between 152 and 181 cases (depending on the trait and the modality analysed) found 'equal' results with both mesh sizes (average $=169.9 ; 89.4 \%$ of cases; Table 4 ). Type I errors ranged from 0 to 18 while type II errors ranged from 0 to 34 (Table 4). Validation of the model created with 'sampling 1' data by means of the comparison of the observed and the expected values for the 'sampling 2' was considered positive; 7 of the 10 variables examined resulted in no significant differences (Table 5). Only densities of Baetis and 'secondary consumers' were underestimated using the 'sampling 1' regression models; the abundance of Oligochaeta was overestimated by the regression model (Table 5).

\section{DISCUSSION}

The analysis of a fraction of the sample, here shown using a fraction trapped in a mesh pore size of $1 \mathrm{~mm}$, can affect descriptors of macroinvertebrate communities (Tanaka \& Leite, 1998; Morin et al., 2004; Rodrigues et al., 2007). In our results, only the Shannon diversity index, the EPT richness and the percentage of primary consumers resulted in similar findings for the two methods we used. We observed that a few taxa (5.2 on average) were only found in the 'total sample' we analysed. The absence of taxa in our study cannot be explained by the body length, however, as maximal body lengths for these taxa range from 2.5 to $40 \mathrm{~mm}$ (Tachet et al., 2002) and individuals could have been retained in the $1 \mathrm{~mm}$ mesh, even at the early stages of their development (see Morin et al., 2004). Nevertheless, the loss of taxa is quite relevant when we consider descriptors such as taxonomic richness and in- 
dices, such as the IBMWP and the IASPT; the addition of new taxa substantially changes the final result. Concerning the IBMWP index, 25 $\%$ of the sites we analysed where classified in a higher quality class when examining the 'total sample'. Our findings suggest that caution should be taken when comparing studies that use different mesh sizes to measure macroinvertebrate community composition.

For the variables we analysed, spatial-temporal comparisons within a given study could be achieved for invertebrates trapped in larger mesh sizes. In our study, changes in the descriptors from the ' $>1 \mathrm{~mm}$ fraction' mesh to the 'total sample' were predictable by linear regression in all cases analysed. Additionally, these linear relationships were relatively constant for most of the taxa or groups we considered, at least for the temporal and spatial range that comprised our samples. Observed statistical discrimination among sites was also very similar considering both fractions. In the Tukey tests, the mean agreement between the betweensite significant differences between the ' $>1 \mathrm{~mm}$ fraction' and the 'total sample' was nearly 95 $\%$. As other studies have concluded (James et al., 1995; Morin et al., 2004; Gruenert et al., 2007) a reliable spatial discrimination between sites can be obtained using a $>1 \mathrm{~mm}$ size fraction.

There are other reasons why a coarse mesh might be used. First, while we have measured density to portray the importance of invertebrates, biomass can also be measured. A more precise estimation can be achieved when trying to solve ecological questions within an energetic perspective. The mesh size used produces a lower bias in biomass, as smaller individuals are the lightest, and their removal from the replicate causes little variation in the final mass estimates (Gage et al., 2002; Morin et al., 2004). Second, the traditional importance given to the structural descriptions of the community (Wright et al., 2000) is giving way to the functional perspective (see Young et al., 2008) that may use structural descriptors as complementary. Within this new approach, estimates based on coarser mesh sizes may be useful and may save time in studies of stream metabolism (Acuña et al., 2005) and of leaf litter processing (Pozo et al., 1998) data.
Third, in a highly complex system, such as river benthos where the number of replicates taken per site from the substrate is highly limited by the effort required to process them, the use of a coarser mesh could allow for the examination of a higher number of replicates (James et al., 1995, Morin et $a l ., 2004)$. This measure could increase the precision, the degrees of freedom and the statistical power of stream macroinvertebrate community analyses (Bartsch et al., 1998; Vlek et al., 2006).

Values of structural descriptors for benthic macroinvertebrates change with mesh size but are predictable as they maintain proportionality among subsamples obtained by different mesh sizes. This linear relationship between the ' $>1 \mathrm{~mm}$ fraction' and the 'total sample' makes internal comparisons possible; we had accurate conclusions on average in $95 \%$ of the cases we examined. The spatial and temporal extent to which this rule applies should be tested in more distanced areas.

\section{ACKNOWLEDGMENTS}

Samples for this work were collected in the RIVFUNCTION (EVKI-2001-00088) project financed by the European Union. Additional financial support was obtained from the Basque Government (IT-422-07). We are grateful to Arturo Elosegi and Oihana Izagirre for providing data on water chemistry.

\section{REFERENCES}

ALBA-TERCEDOR, J. \& A. PUJANTE. 2000. Running-water biomonitoring in Spain: opportunities for a predictive approach. In: Assessing the Biological Quality of Freshwater: RIVPACS and similar technique. J. F. Wright, D. W. Sutcliffe \& M. Furse (eds.): 207-216. Freshwater Biological Association.

ACUÑA, V., I. MUÑOZ, A. GIORGI, M. OMELLA, F. SABATER \& S. SABATER. 2005. Drought and postdrought recovery cycles in an intermittent Mediterranean stream: structural and functional aspects. J. N. Am. Benthol. Soc., 24: 919933. 
BARBOUR, M. T. \& J. GERRITSEN. 1996. Subsampling of benthic samples: a defense of the fixedcount method. J. N. Am. Benthol. Soc., 15: 386391.

BARTSCH, L. A., W. B. RICHARDSON \& T. J. NAIMO. 1998. Sampling benthic macroinvertebrates in a large floodplain river: considerations of study design, sample size and cost. Environ. Monit. Assess., 52: 425-43.

BATTLE, J., J. K. JACKSON \& B. W. SWEENEY. 2007. Mesh size affects macroinvertebrate descriptions in large rivers: examples from the Savannah and Mississippi Rivers. Hydrobiologia, 592: 329343.

BEGON, M., J. L. HARPER \& C. L. TOWNSEND. 1997. Ecología: individuos, poblaciones y comunidades. Omega (ed.). Barcelona. 605 pp.

BONADA, N., N. PRAT, V. H. RESH \& B. STATZNER. 2006. Developments in aquatic insect biomonitoring: a comparative analysis of recent approaches. Annu. Rev. Entomol., 51: 495-523.

BOONSOONG, B., N.SANGPRADUB \& M. T. BARBOUR. 2009. Development of rapid bioassessment approaches using benthic macroinvertebrates for Thai streams. Environ. Monit. Assess., 155: 129-147.

BUSS, D. F. \& E. L. BORGES. 2008. Application of Rapid Bioassessment Protocols (RBP) for benthic macroinvertebrates in Brazil: Comparison between sampling techniques and mesh sizes. Neotropical Entomology, 37: 288-295.

CAO, Y., D. D. WILLIAMS \& N. E. WILLIAMS. 1998. How important are rare species in aquatic community ecology and bioassessment? Limnol. Oceanog., 43: 1403-1409.

CIBOROWSKI, J. J. H. 1991. Estimating processing time of stream benthic samples. Hydrobiologia, 222: 101-107.

COURTEMANCH, D. L. 1996. Commentary on the subsampling procedure used for rapid bioassessments. J. N. Am. Benthol. Soc., 15: 381-385.

ELOSEGI, A., A. BASAGUREN \& J. POZO. 2002. Ecology of the Agüera: a review of fourteen years of research in a Basque stream. Munibe (Ciencias Naturales-Natur Zientziak), 53: 15-38.

GAGE, J. D., HUGHES, D. J. \& GONZÁLEZ VECINO, J. L. 2002. Sieve size influence in estimating biomass, abundance and diversity in samples of deep-sea macrobenthos. Mar. Ecol. Prog. Ser., 225: 97-107.
GRUENERT, U., G. CARR \& A. MORIN. 2007. Reducing the cost of benthic sample processing by using sieve retention probability models. Hydrobiologia, 589: 79-90.

JAMES, R. J., M. P. LINCOLN SMITH \& P. G. FAIRWEATHER. 1995. Sieve mesh-size and taxonomic resolution needed to describe natural spatial variation of marine macrofauna. Mar. Ecol. Prog. Ser., 118: 187-198.

LARRAÑAGA, A. 2008. Effects of eucalypt plantations and eutrophication on stream shredders trough the analysis of biological traits and biochemical composition. Ph. D. Thesis. University of the Basque Country. 177 pp.

LARRAÑAGA, A., A. BASAGUREN, A. ELOSEGI \& J. POZO. 2009. Impacts of Eucalyptus globulus plantations on Atlantic streams: changes in invertebrate density and shredder traits. Fundam. Appl. Limnol., Arch. Hydrobiol., 175: 151-160.

METCALFE-SMITH, J. L. 1996. Biological waterquality assessment of rivers: use of macroinvertebrate communities. In: River Restoration. G. Petts \& P. Calow (eds.): 17-59. Blackwell Science, Oxford, UK.

METZELING, L. \& J. MILLER. 2001. Evaluation of sample size used for the rapid bioassessment of rivers using benthic macroinvertebrates. Hydrobiologia, 444: 159-170.

MORIN, A., J. STEPHENSON, J. STRIKE \& A. G. SOLIMINI. 2004. Sieve retention probabilities of stream benthic invertebrates. J. N. Am. Benthol. Soc., 23: 383-391.

POZO, J., A. BASAGUREN, A. ELOSEGI, J. MOLINERO, E. FABRE \& E. CHAUVET. 1998. Afforestation with Eucalyptus globulus and leaf litter decomposition in streams of northern Spain. $H y$ drobiologia, 374: 101-109.

RODRIGUES, A. M., S. MEIRELES, T. PEREIRA \& V. QUINTINO. 2007. Spatial heterogeneity recognition in estuarine intertidal benthic macrofaunal communities: influence of sieve mesh-size and sampling depth. Hydrobiologia, 587: 37-50.

TACHET, H., M. BOURNARD \& P. RICHOUX. 2002. Invertébres d'eau douce: systématique, biologie, écologie. Paris: CNRS editions. 587 pp.

TANAKA, M. O. \& F. P. P. LEITE. 1998. The effect of sieve mesh size on the abundance and composition of macrophyte-associated macrofaunal assemblages. Hydrobiologia, 389: 21-28. 
TORRALBA BURRIAL, A. \& F. J. OCHARAN. 2007. Comparación del muestreo de macroinvertebrados bentónicos fluviales con muestreador surber y con red manual en ríos de Aragón (NE Península Ibérica). Limnetica, 26: 13-24.

VINSON, M. R. \& C. P. HAWKINS. 1996. Effects of sampling area and subsampling procedure on comparisons of taxa richness among streams. J. N. Am. Benthol. Soc., 15: 392-399.

VLEK, H. E., F. SPORKA \& I. KRNO. 2006. Influence of macroinvertebrate sample size on bioassessment of streams. Hydrobiologia, 566: 523542.

WALSH, C. J. 1997. A multivariate method for de- termining optimal subsample size in the analysis of macroinvertebrate samples. Mar. Freshw. Res., 48: 241-248.

WRIGHT, J. F., M. SUTCLIFFE \& M. T. FURSE (eds.), 2000. Assessing the biological quality of freshwaters. Freswater Biological Association. Ambleside, Cumbria, UK. 256 pp.

YOUNG, R. G., C. D. MATTHAEI \& C. R. TOWNSEND. 2008. Organic matter breakdown and ecosystem metabolism: functional indicators for assessing river ecosystem health. J. N. Am. Benthol. Soc., 27: 605-625.

ZAR, H. J. 1999. Biostatistical analysis, $4^{\text {th }}$ ed. New Jersey: Prentice-hall. 663 pp. 